DOI: 10.2478/v10141-009-0031-z

\title{
Do Major Sports Events Enhance Tourism Destinations?
}

\author{
Patrizia Zagnoli, Elena Radicchi
}

University of Florence, Italy

ABSTRACT

KEYWORDS major sport events; tourism destinations; sport marketing; qualitative local

\begin{abstract}
development; urban renewal; socio-cultural regeneration
A growing number of destinations are utilizing sport events as a strategic tool for revitalizing and re-qualifying themselves. The aim of this paper is to explore the value of sport events in enhancing the "quality" (in terms of image, tourist attractiveness, quality of life, etc.) of a tourist destination. This assessment is based on a case study analysis regarding the effects of sport initiatives adopted by a number of cities and countries in Italy, Europe and worldwide. The findings suggest that sport events can have different implications for host destinations: from fostering an economic and social urban "regeneration", to putting a city on a worldwide tourist map, or even changing the unequal participation of a country in the global economy.
\end{abstract}

\section{Introduction}

Sporting activities are becoming more and more important aspects of the leisure industry (Varaldo 2002, Zagnoli, Radicchi 2008a). In particular participation and attendance at sports events have become an increasing proportion in the recreational and entertainment lifestyle of people (Resciniti 2004). Despite the existence of a wide range of events in the sport sector - from experiential marketing events (Zagnoli, Radicchi 2008b) to small local initiatives, sports training camps and matches of professional sports teams this research focuses on major sports events (i.e. the Olympics, football World Cup, America's Cup), that is any large-scale event which (Hall 1989, Hiller 1998, Payne 2007, Ritchie 1984):

- is of fixed duration and on a short basis;

- is hosted not necessarily in one city, but even across a country;

- attracts a huge number of participants and spectators;

- has a great appeal to media at international level;

- means a relevant amount of investment (economic, infrastructure, logistic services, safe and security management, etc.) by host destinations;

Staging major sports events is a key objective of many governments and city marketers worldwide, since these may have a catalytic role in the tourist development of host destinations. 
Although the economic impact of major sports events is the most common issue discussed in the literature (Dabinett 1990, Getz 1997, Kurtzman 2005, Mastermann 2004), other factors on the host destinations' development include (Chalkey, Essex, 1999, Smith 2005, Weed, Bull 2004, Whitson 2004):

- enhancing international tourism attractiveness;

- reorienting the image of a place;

- boosting urban regeneration and renovation;

- improving quality of life for visitors and citizens.

The aim of this paper is to analyze the effects of a major sports event on the tourist development (in terms of image, tourist attractiveness, urban renewal, quality of life, etc.) of the host destination. The research methodology is based on a multi-cases study analysis (Yin 2002) concerning major sport initiatives in a number of host places in Italy, Europe and worldwide. Results from previous research developed within the Laurea Specialistica in Management dello Sport at the University of Florence were used to undertake the case studies (primary source). A meta-analysis of salient research related to sports events management (i.e. Bowdin et al. 2001, Chalip 2006; Masterman 2004), sport tourism destination (i.e. Higham 2005, Weed, Bull 2004) and urban development (i.e. Chalkley, Essex 1999), was also conducted (secondary source). Analytical categories to explore the implications of major sports events on host economy development were mainly extrapolated from tourism destination management bibliographical resources (Chalip 2006, Higham 2005, Whitson Macintosh 1996) (§. 2). Although destination management focuses on planning strategies of tourism destinations, indicators discussed within this literature are useful to verify the long-term efficacy and efficiency of governments' policies regarding the staging of a major sports event and therefore to make an evaluation of the host economy qualitative development.

Findings suggest that major sports events can have different implications for tourism destinations: from fostering economic and social urban regeneration, to putting a city on a worldwide tourist map, or even changing the unequal participation of a country in a global economy (§. 3). Although the proposed research is not expected to be exhaustive, the case studies along with the review of the selected literature allowed the development of a primary typology of host economy qualitative development (§. 4).

\section{Key indicators for tourism destination development}

According to numerous authors (Allen et al. 2002, Bowdin et al. 2006, Chalip 2006, Getz 1997, Preuss 2000, 2007, Ritchie 1984) major sports events' potential impacts on host destinations development fall into five main categories (see Figure 1):

- economic development;

- tourism increasing;

- urban renewal;

- socio-cultural regeneration;

- environmental development. 
Figure 1. Key indicators for a tourism destination development

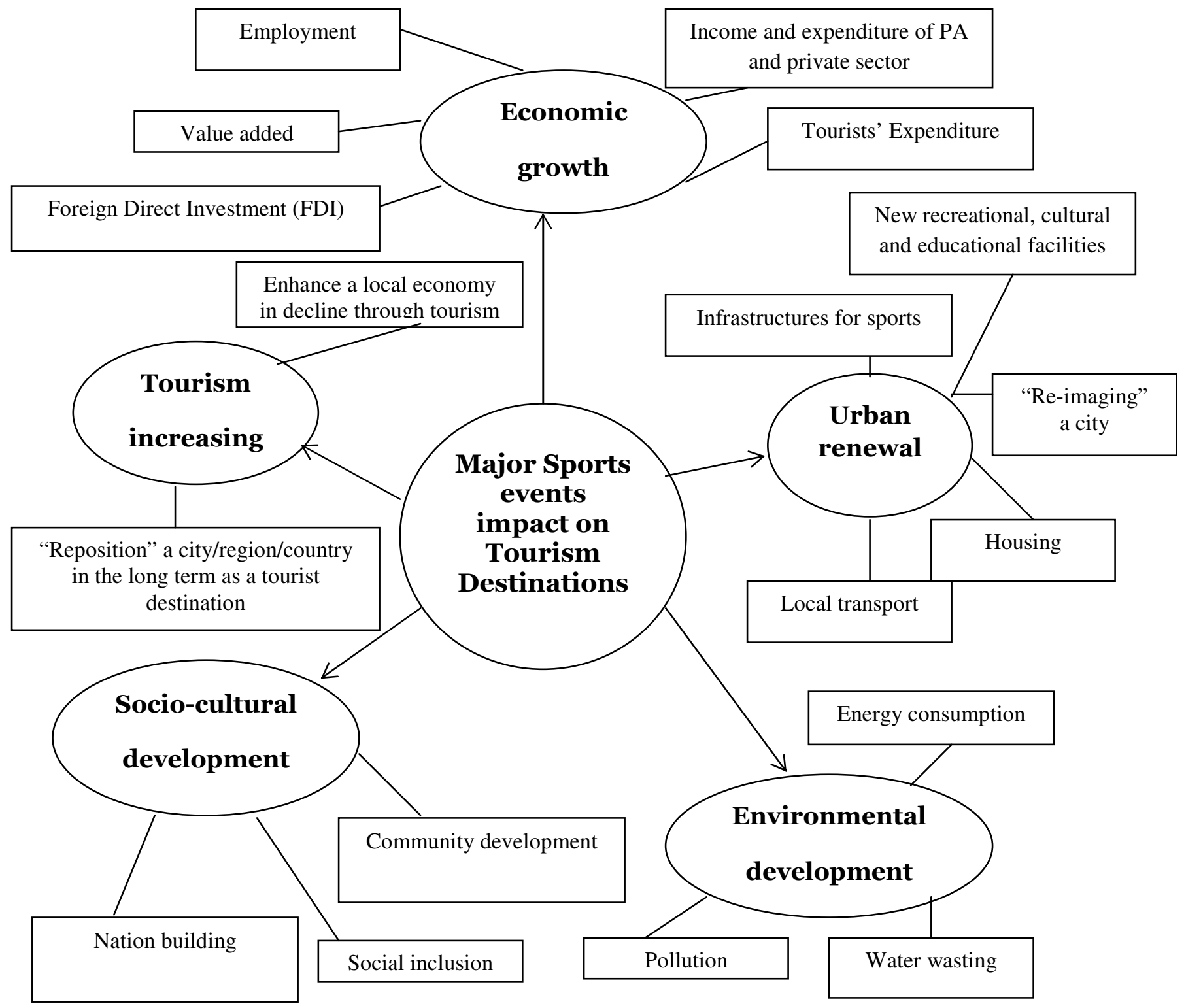

Events' effects on host destinations can have both tangible and intangible multiple dimensions (Grant Thornton 2003, OMERO 2006). Among tangible components are:

- increasing tourism;

- rising employment;

- new sporting and non-sporting infrastructures;

- leisure facilities, etc.

The intangible dimensions include:

- re-imaging of a city;

- diffusion of sports values;

- improvement of know-how in managing sports events;

- nation-building, etc. 
The following section analyzes some of the key indicators and sub-elements concerning the role of sport on tourist destinations development.

\subsection{Economic growth ${ }^{1}$}

The economic benefits of sport activities include the increase in income generated by hosting such events and an increase in the employment rate as a result. The income increase is usually correlated to capital investment made by public administration and/or private sector not only for sports venues (stadiums, arena, ballparks, etc.), but also to regenerate urban areas (e.g. subways, roads, railways, airport upgraded, car parking, city restyling, etc.) and enhance tourist facilities (hotels, restaurants, leisure and entertainment services, etc.). One example is the 2006 Turin Winter Olympics, that brought for the Piedmont region an added value of $€ 13$ billion and a $2.8 \%$ increase in the rate of employment ${ }^{1}$. The sectors gaining the greatest benefits in terms of added value and employment would be construction, commerce, hotels and restaurants ${ }^{2}$.

Another key economic indicator is the additional amount of spending by visitors on such items as accommodation, food, local transportation, rental cars, shopping and entertainment. The Super Bowl, one of the most-attended U.S. sports event, which in 2007 was held in Miami, brought more than 112,000 fans to South Florida with an average visitor spending of \$664 per day (Miami Herald 2007). These figures can be easily understood considering that the Super Bowl is first and foremost an entertainment event and only secondarily a sports event, involving a whole week of festivities, ceremonies, pre-game shows, etc. which have a huge potential impact on host local economy.

Even though there is only little research concerning the role of sports events in attracting foreign direct investments (FDI) on host places (e.g. Bohlmann, Van Heerden 2005), it can be argued that a major sports event may enhance the international status of a city or a country as a global business hub by increasing its infrastructure in terms of telecommunications, transports, new residential areas, and a better quality of life. A successful example is Atlanta (Georgia) which in 1996 hosted the Summer Olympics. National and international recognition of the city and state through extensive media exposure enhanced its reputation as one of the world's leading business cities which in turn stimulated the relocation of many major companies in this area ${ }^{3}$.

\subsection{The increase in tourism activities}

Event tourism is a key aspect of host destinations development. Major sports events are seen as catalysts for attracting visitors and increasing their average spend and length of stay during the event. They are also seen as image-makers of a place, developing high profiles for cities and/or countries, repositioning them as tourism attractions (Getz 1997).

Some cities worldwide are easily recognizable by unique "physical icons" (Higham 2005, p. 78) - for example Paris has the Eiffel Tour, New York has the Statue of Liberty, Rome has the Coliseum. Other places are as well known at a global level for any cultural, historical and/or artistic

\footnotetext{
${ }^{1}$ Source: Unione Industriale Torino (2005), Valutazione degli effetti economici dei Giochi Olimpici Invernali di Torino 2006, November.

${ }^{2}$ Source: Unione Industriale Torino (2005), Ibid.

${ }^{3}$ More than ten years later the 1996 Olympics, in 2006 Atlanta was home to nearly 1,600 international companies that employed more than 80,000 people. More than $20 \%$ of expansions and relocations to Atlanta in the last 10 years were from other countries so that Atlanta has 50 foreign consulates, 31 foreign chambers of commerce and 18 sister cities. Source: Metro Atlanta Chamber of Commerce (2006), "10 years later: Atlanta's Olympic legacy is still transforming city".
} 
asset. These destinations need to try to "reorient their image" (Smith 2005) and raise their value by developing major sports events. Melbourne, for example, has worked to make its image more appealing to foreign visitors through a strategic use of sports. Hosting international sporting events such as the 2003 Rugby World Cup and the Melbourne $\mathrm{Cup}^{4}$ (horse racing), the city not only gained immense exposure as a sport tourism destination during the events, it also became an attractive place for all "active sport" tourists (Higham 2005).

Hosting sport events also has the potential to develop a local economy, by providing an increase in tourism spending connected to the sport activity even beyond the event period. With over 75 million NASCAR ${ }^{5}$ fans all over the United States (NASCAR 2006), there is a huge opportunity for North Carolina to advance its tourism industry in a "state where traditional economic engines of tobacco and textiles are going" (Spanberg 2003). In 2007 domestic tourists spent more than $\$ 16$ billion (7.2\% increase over 2006), generating a total of more than $\$ 1.3$ billion in tax revenue and contributing to the increase of up to $2 \%$ in local travel and tourism employment (North Carolina Dept. of Commerce, 2008). Most of the tourism income across the state is primarily brought in by the state's biggest cities such as Raleigh and Charlotte where NASCAR's circuits are settled. Since North Carolina is considered the hub of NASCAR, with more than 50 teams locally based, it sees an influx of visitors who not only travel here to attend racing events, but also to visit the "cluster of team race" with shops, race-related museums and other services facilities (Higham 2005).

\subsection{Urban renewal}

Hosting a major sports event is often viewed as a potentially important tool in urban regeneration. It does that by bringing the opportunity to improve the infrastructure and appearance (new buildings, new architecture, etc.) of the host city (tangible dimension), and it also gives the opportunity to transform its image (intangible dimension), in essence a chance to "recreate its personality” (Smith 2005).

To a tangible level, bidding for a major event such as the Olympic Games, the football World Cup or the rugby World Cup means funding a substantial capital infrastructure projects, not only in terms of sport facilities and venues (new or renewed stadiums and arena, building the athletes village, etc.), but also in terms of municipal and national transformation. In their history the Olympics are traditionally used as a vehicle to undertake long-overdue improvements to transportation and housing in depressed parts of a city (Payne 2007). London, which will host the 2012 Summer Olympics, besides undergoing extraordinary sport construction work $^{6}$, will dramatically improve local transportation, from roadways to the London Underground ${ }^{7}$. The social payoff for East London will be a revitalized neighbourhood with 9,000 new, largely low-cost homes and brand new recreational, cultural, and educational facilities (Payne 2007).

Major sports events are generally also a part of a city's wider strategy for modernization to increase tourist appeal (Roche 2000). For example the redevelopment of Faleron Bay in Athens had

\footnotetext{
${ }^{4}$ http://www.melbournecup.com.

${ }_{6}^{5}$ National Association of Stock Car Racing (NASCAR).

${ }^{6}$ Including an 80,000-seater stadium as well as eight other arenas, an Olympic Village to house 17,000 athletes and officials, and the largest urban park created in Europe in 150 years. Source: Payne M. (2007), "A Goldmedal Partnership", Strategy+Business, Issue 46, pp. 1-12.

${ }^{7}$ Olympic Javelin high-speed shuttle trains will transfer passengers between the Olympic site and mainland Europe in just 45 minutes, with a train arriving in London every 15 seconds during peak times. Source: Payne (2007), Ibid.
} 
been a municipal regeneration aim since the early $1960 \mathrm{~s}^{8}$ and formed the basis of the city proposals for its candidature for the 1996 and 2004 Summer Olympic Games (Mastermann 2004). The project purposes were clearly not only to prevent floods and upgrading the coastal area, but even establishing a metropolitan attraction pole for citizens and visitors 9 . After having hosted the 2004 Olympics, this area of the city is now provided with a number of new leisure and entertainment facilities which include a water plaza and esplanade, nautical sports complex and an open-air amphitheatre that during the games was the beach volley arena ${ }^{10}$.

To an intangible level, the term urban renewal refers to "attempts by destinations to reconfigure their conceptions" (Smith 2005, p. 219). For example such efforts have allowed many post-industrial cities to stimulate an urban transition from the established industrial sectors to the offer of new cultural services (see §. 3.4).

\subsection{Socio-cultural development}

The impact of a sports event must be seen not solely in terms of economic, infrastructural and tourism development, but to a greater extent on social processes and relationships (Coalter et al., 2000). At a social level sport can make a contribution to nurturing community and youth development, personal skills and employment opportunities.

For example in the long-term a major sports event may enhance a "social glue" (Coalter et al., 2000) among a local or national community through the shared sense of belonging or common purpose. To achieve community development, a greater degree of social cohesion and increased inclusion are required. To reach this goal, citizens would need to have facilities which promote social contacts and recreational networks. Sporting facilities built for the occasion of a major event that become multipurpose and accessible to all, may contribute to social cohesion particularly in areas of economic and social deprivation, and provide wider value to local communities such as through development of community sports hubs (§. 3.4).

Major sports events also present opportunities for the development of new skills and professional qualifications. Through the involvement in the organisation of sports initiatives, individual participants can increase personal and social skills, self esteem and self confidence enhancing their "employability" to a future job in any sector, not just in sports.

\subsection{Environmental development}

Sports activities can strongly and significantly interact with the environment. It is therefore important for major sports events to be "sustainable" (Kaspar 2001) and "eco-efficient" (Koivusalo

\footnotetext{
${ }^{8}$ By the end of the 20th century, Athens had absorbed close to $40 \%$ of the population and most of the economic activities of Greece. As a result, it experienced a rapid expansion of its urban fabric in all directions, down to the shores of the Saronic Gulf. Nevertheless, Athens did not become a coastal city and its relation with the sea remained undefined, both functionally and aesthetically. The situation deteriorated in the 1960s and 1970s with the construction of a raised rapid traffic artery along the Faleron coast (Poseidon Avenue) and the backfilling of large parts of the beachfront. The result was the creation of an extensive no-man's land in a most privileged location, and the condemnation of the residents along the coast to noise, pollution and constant flood threats. Since the 1970s and due to the strategic location of Faleron in the network of the functions of the capital, various efforts were made to improve the area. These, however were never implemented, while Faleron continued to deteriorate. Source: Ministry of Environment, Physical Planning and Public Works, Regeneration of Faleron Bay, Olympic Projects 2004.

${ }^{9}$ See footnote 9.

${ }^{10}$ See footnote 9 .
} 
2005) which means adopting a management strategy that links financial and environmental performance to create more value with an ecological impact.

Two areas of concern must be analyzed when speaking about the environmental implications of major events (Carbone 2007, Kaspar 2001):

- impact on nature of sport venues and/or infrastructure;

- $\quad$ post use of sports facilities and infrastructure.

The most visible impact of major events is the amount of natural environment used. In this regard, organizers must carefully select the areas for new sporting venues and facilities and balance sports needs with environmental constraints, especially in protected areas. Today potential exists for the construction of environmentally-friendly buildings which save energy and use local building materials that are harmonious with the surrounding environment. Examples of "eco-efficient actions" are temporary roofs and fitted carpets at the stadiums that can be reused and recycled after the event and/or venues that can save energy in terms of lighting and heating ${ }^{11}$.

Transport is another central issue for any organizer, and distances between the venues should be as short as possible. Generally, incentives must be given to make public transport as efficient and attractive as possible for the spectators. Any environmental innovation such as bio-fuel, electric or hybrid cars is beneficial to the environment.

Implementation of community recycling systems, waste separation and avoidance programmes can also benefit the host community and its guests during the event. Multi-use cups and recyclable materials, as well as a recycling system, are important factors in creating an environmentally-friendly waste system.

The analysis of post-use possibilities is also of key importance in terms of urban environmental impact. Cities should plan in advance the after-use of sports events facilities in order to avoid their obsolescence. For example, the Millennium Stadium in Cardiff, built to stage the 1999 Rugby World Cup was designed to ultimately house different events and not just sports (Mastermann 2004). The location for the venue is very accessible to downtown Cardiff and is a catalyst of the citizens' entertainment life.

\section{A tentative framework for qualitative development of tourism destinations}

Through the analysis of some major sports events which have been already concluded or that will be staged in the near future in a number of cities and countries in Italy, Europe and worldwide, this section proposes a preliminary framework for the tourism destinations development. Different typologies to be followed are based on the extent to which indicators and sub-elements discussed above (see $\S .2$ ) would have impacted a specific area such as a city, region or country.

\subsection{Putting "periphery" destinations on the global map}

Many cities have sought to change the somewhat "provincial image" (Whitson 2004) they had historically, using international sports events to reposition themselves on the world stage.

\footnotetext{
${ }^{11}$ For example the 2008 Beijing National Aquatics Centre, better known as the "Water Cube", which has three pools below ground level is made up of a steel skeleton sheathed in a Teflon-like plastic resembling bubbling water. This translucent shell lets in sunlight, providing heat and light and cutting energy use by up to $30 \%$. Source: Bonadies, 2008.
} 
For example, before the 1992 Olympics, an industrial crisis affected the city of Barcelona not only from the economic point of view but also in social terms. There was a lack of infrastructure and effective policies to increase competitiveness and social change. During the period 1987-1991, efforts were made to develop and improve the city, coinciding with the bidding to host the Olympics (Bontje, Pareja 2007).

The slogan of the Summer Games was "Put Barcelona on the Map", highlighting the will of the Spanish city to present itself to the world as an internationally known modern urban centre. Planning strategies of Barcelona to bid for the 1992 Olympics were may be also linked to its "capital city" aspirations (Monclùs 2000). The idea of hosting international events has been in some way a means of enhancing the Catalan identity and challenging the ascendancy of Madrid. However, Barcelona's main purpose was not to affirm its signs of identity as a political capital, in contrast to the traditional industrial character of the city, but rather to demonstrate that it could be an attractive "cultural capital" in the same way as an "economic capital" (Monclùs 2000).

The 1992 Olympic Games in Barcelona have primarily provided a catalyst and a context for a general physical urban renewal (§. 2.3) of the city. Opportunities were taken to promote several different infrastructure rejuvenations such as (Ferran 2004):

- construction of many sports venues and facilities;

- building of new houses, offices and hotels;

- renovation of local roads and transport infrastructure;

- huge capital investments to restore the old harbour which have lately become the most important centre for leisure and entertainment city life.

Barcelona'92 is one of the most successful example cited in the literature (Bontje, Pareja 2007, Chalkey, Essex 1999, Kurtzman 2005) for its "extraordinary and sustained capacity to ride the Olympic wave" (Ferran 2004). In fact, the Olympics were only a turning point in the urban and socioeconomic growth of Barcelona, following the "event-related" path of city development. Many of the improvements achieved with the Olympics (i.e. enhanced infrastructures, worldwide media coverage, etc.) were later used by the local government as a strategic axis for "branding the city" (Bontje, Pareja 2007).

Since the conclusion of the Games, Barcelona - through an active partnership between the public and the private sector - has continued to heavily invest in numerous projects (culture, architecture, art exhibitions, congresses, events, etc.) aimed at promoting certain activities which are considered of high priority in the international competitive arena such as design, universities and information technologies ${ }^{12}$. This commitment has contributed to the urban and image transformation of Barcelona which today is placed on the map of international cities considered desirable places to live, to visit or to locate a business.

A more recent example of a city's repositioning is Valencia, which in 2007 hosted the "Louis Vuitton America's Cup". This is the most prestigious sailing competition in the world and involves investment of such extent that it can generate substantial economic impact on output, value added and employment (§. 2.1) for the designated host city (Ivie 2007).

\footnotetext{
12 According to the Metropolitan Strategic Plan of Barcelona, a platform of initiatives have been developed aimed at determining the competitiveness of the city in several fields. As examples: the Biomedical Research Park (PRBB) which works together with the University Pompeu Fabra and the nearby Hospital del Mar in order to promote innovation and high quality research; the Barcelona Design Centre, a private non-profit foundation, whose mission is the international diffusion and promotion of Barcelona as a design capital; the 22@ Barcelona Media Park, which is now under construction, is an attempt to create the environmental conditions for the cluster location of highly innovative and creative enterprises. Source: Bontje, Pareja (2007).
} 
For years Valencia has been seen as a "poor cousin" to the capital Madrid and to Barcelona despite having a vibrant economy in industry, services and culture ${ }^{13}$. By hosting the 32nd America's Cup edition, Valencia has received an international exposure because of the regattas being broadcast by the media worldwide. The media coverage during the event has "sold the city globally" (Jones, 2005, p. 186), encouraging further visits (§. 2.2) and perhaps inward investment in the longer term (§. 2.1).

The most noteworthy impact of the event was in terms of physical urban infrastructures ( $\$$. 2.3). Besides general improvements of the highway and railway network, the restoration of bridges and monuments, and the construction of gardens, parks and libraries, Valencia ${ }^{14}$ has invested more than $€ 400$ million in the harbour's renewal (Ivie 2007), building new facilities complete with superyacht quays and faster access to the sea ${ }^{15}$. The harbour's rejuvenation also attracted private investment to build luxury hotels and nightclubs and advance the seafront with restaurants, shops, and entertainment facilities.

In view of the 2007 America's Cup, Valencia invested a budget of $€ 122$ million for the extension of the city's airport at Manises. The project incorporated a Metro station which terminates at the airport and an increase in the number of car parking places.

The economic benefits (\$. 2.1) of the event surpassed the costs incurred. It has been estimated that the race generated an added value of about $€ 2.7$ billion and the increase in total demand associated with the America's Cup increased the employment by 73,800 jobs (Ivie 2007). Furthermore, the event has contributed to developing the local economy with many of the small family companies placed around Valencia which have started working in high-tech sailing and marine sectors.

The promotional effect may be more relevant than the immediate impact in terms of visitors expenditures ${ }^{16}$ and added value for the local community. Before being designated host, Valencia had already started its own transformation process and met important requirements in terms of infrastructure, facilities, and services. Nonetheless, the international projection that the America's Cup brought along with the infrastructural investment into the old harbour, has helped Valencia to change its image to become an attractive urban pole not only for the Spanish south coast but also for Europe.

\footnotetext{
${ }^{13}$ The city maintains an important industrial base which is made up of small and medium-sized companies. Some of the most important are in the areas of printing and graphic arts, wood and furniture, metallic products and footwear and clothing. The economy of the city has enjoyed positive dynamic growth during recent years. The dynamism of the city as an economic centre is also reflected in the strength of institutions which are key for economic development, such as the Valencia Trade Fair, the Autonomous Port, the Stock Exchange, the Palace of Congresses or its Universities. Valencia also has a number of important cultural institutions that are becoming increasingly important in the development of the city: the IVAM (Valencia Institute of Modern Art), the Palace of Music or the City of Arts and Sciences all contribute an undeniable added value to the city and to its metropolitan surroundings as a centre of culture and leisure. Source: Valencia Tourist Board.

${ }^{14}$ Investments with the objective of providing Valencia with the necessary infrastructure to host the event have been made by a pool of actors such as the Valencian Government (through the Action Plan for the America's Cup), the "Consorcio Valencia 2007", the Central Government, and the Valencian City Hall. Other agents invested as a result of the sports event. Source: Ivie (2007), Final Report on the Economic Impact of the $32^{\text {nd }}$ America's Cup Valencia 2007.

${ }^{15}$ The port includes, among other things, the opening of a canal that connects the inner dock with the sea allowing participating boats to be in place for the regatta in just 15 minutes. Furthermore there are bases for the participating teams, a guest centre, a communication centre, and a park for 8,000 spectators, restaurants, cafés, and stores. Source: Ivie, 2007, Ibid.

${ }^{16}$ The expenditure we can call "tourist" made by the $1,740,000$ people who visited Valencia's Port during the regattas held from April to July 2007, spending more than $€ 106$ million. Source: Ivie (2007), Ibid.
} 


\subsection{Developing emerging markets' economies}

One common thread for the emerging economies has become the view that sport events and sport facilities development have become a central feature in their promotional strategy to enhance economic development and retain tourist appeal. There are also some differences that exist among developing economies.

One example is in Asian economies, in particular the Middle East, where sport is becoming a driving economic force aiding them in becoming global business centres. Although at different stages of development, in many Middle East countries governments actively push participation in such events. With the support of huge capital investment by private companies, banks, real estates, etc. the region is also developing infrastructure and hosting world-class sport events in order to attract financial income, elite tourists and foreign corporations to the region.

- Abu Dhabi, commercial capital city of Dubai (UAE) ${ }^{17}$, is focusing on becoming one of the world's premier luxury tourist destination ${ }^{18}$ by hosting elite sports - such as golf and motor sport - as well as various other cultural activities $^{19}$. Central to reaching this target is the development of a range of international sporting events, designed both to attract spectators and showcase the nation in the media. One such project is the development of the "Ferrari World theme park" ${ }^{20}$ which will be built near by the new $5.6 \mathrm{~km}$ motor racing circuit being constructed to host the Formula One Grand Prix from 2009.

Apart from the motor racing, Abu Dhabi has recently announced plans to host the world's richest cycle race ${ }^{21}$ - the ten-day, three-stage "Race of Champions". The $204 \mathrm{~km}$ event will be held annually for the next five years.

Golf is highlighted too, with the "European PGA Abu Dhabi Golf Championship" entering its third year in 2008 .

- Bahrain has heavily invested in motor sport racing with the construction of the Bahrain International Circuit (BIC). BIC is becoming a catalyst for business developments within the Kingdom of Bahrain. Not only at the circuit, but also across the country there are numerous financial and commercial companies that have benefited from the promotion of hosting the only round of the FIA Formula One World Championship in the Middle East. With a worldwide media coverage of 540 million viewers (FIA 2007), the race gives a global exposure to the country and the region.

- Qatar is host to several major sporting events, mainly world-class athletic competitions. By hosting events such as the Asian Games (2006), Qatar is trying to elevate its position in the global arena and adding to international awareness of its potential as a sports events and tourist destination.

The building of indoor sport facilities, motor sport circuits, a Ferrari theme park, and other leisure and entertainment venues should promote and enhance the image of United Arabs Emirates,

\footnotetext{
${ }^{17}$ United Arabs Emirates (UAE).

${ }^{18}$ In 2006, about 8 million visitors came to the UAE. Source: Euromonitor International, Travel and Tourism in the United Arabs Emirates, Report, 2008.

${ }^{19}$ Most of Abu Dhabi's tourism plan is centred around the redevelopment of Saadiyat Island, a $27 \mathrm{sq} \mathrm{km}$ island to the north of Abu Dhabi city, which will become the new Cultural District featuring the Guggenheim Abu Dhabi, the Louvre Abu Dhabi, the Biennale Park, and a Maritime Museum. Source: Abu Dhabi Authority for Culture and Heritage, 2008.

${ }^{20}$ This leisure facility, being built on Yas Island just minutes away from the international airport, will feature simulator rides, roller coasters, race track, an interactive museum and a theatre.

${ }^{21}$ Some of the world's top cyclists and teams are expected to compete for $\$ 1$ million in prize money.
} 
Bahrain and Qatar and may be an interesting opportunity to put these countries on the international tourist maps, also providing an important economic development.

China is another important emerging country on the global market place. Unlike in the Middle East, the economic situation in China is highly differentiated throughout the nation state. Although over the last years the country has experienced a sustained growth in Gross Domestic Product (GDP), a rising number of Chinese entrepreneurs, massive foreign investment and more economic liberalization (Ashton 2002), only for a small part of the population has disposable income risen sharply ${ }^{22}$ and most Chinese still live in rural areas, under social and educational conditions well below the level of Western countries.

The business of sport in China is absolutely fragmented too, and an economic, tourist, sociocultural development generated by a sports event may only be accounted in some specific areas of this country.

For example, in the case of the 2008 Beijing Olympics, the most relevant implications have been mainly for the host city. However, as for other Olympic games, staging this global event have contributed to enhancing China's image worldwide.

Local politicians and organizers have dedicated huge infrastructural projects that are very much needed for the general development of the city. There are, for example, the new ring roads, subway lines, airport terminals, coal-burning power plants to reduce emissions, water treatment facilities, and the planting of millions of trees ${ }^{23}$.

The 2008 Summer Olympics investments might not have significantly fostered direct economic advancement in Beijing, but the implications have been mainly indirect with local tourism increasing and social regeneration (Preuss 2007).

The media coverage during the Games has diffused throughout the world the message about sufficient infrastructure, better air, good living conditions, state-of-the-art telecommunications, modern tourist accommodations and hotels, etc., in essence a kind of local marketing promotion of Beijing as a new tourist destination. The change of location factors in the city did also attract additional foreign investment, thus enhancing the productivity of this destination as a central business district (Wei, Yu 2006).

Through the huge capital investment in sports venues and other physical facilities, Beijing organizers also contributed to developing nation-building (§. 2.4) signalling to the local population self-confidence in their own strength with the intention to reduce a feeling of inferiority to other nations (Preuss 2007).

Hosting an international event which led million of visitors to Beijing also means "educating" the local population toward a more "civil behaviour" and fostering interpersonal relationships of Chinese with other people ${ }^{24}$.

\footnotetext{
${ }^{22}$ In fact, consumer wealth is concentrated in the main cities or conurbations with the top six consumer markets being Beijing, Shangai, Chengdu, Chongqing, Guangzhou and Wuhan. Source: Ashton, 2002.

${ }^{23}$ This makes Beijing appear as the most expensive Games in Olympic history with an overall investment reported to be approximately US\$50 billion. Source: Preuss, 2007.

${ }^{24}$ The "Beijing Speaks English Program," was introduced in 2001 aiming for 400,000 fluent English speakers by 2008. As part of the program, English classes start in first rather than third grade. Government and private employees were encouraged to learn with vacation and financial incentives. In recent months, the English campaign has been joined by efforts to clean up "bad behaviours" such as spitting and littering, queuing and table manners, under the slogan "Prepare for the Olympics, Strive for Civility and Create New Habits!". Source: http://www.ir2008.org/olympics.
} 
Furthermore, the 2008 Games have contributed to improving natural environment (§. 2.5). Despite concerns about local air pollution, under the Beijing Sustainable Development Plan the city launched many projects ${ }^{25}$ to advance the quality of Beijing's environment, with an overall investment of \$12.2 billion (UNEP 2007).

\section{3 "Mise en valeur" of local assets}

Environment is fundamental to the prosperity of many places (Tribe 2005). Qualitative growth of a local context can be enhanced by the "mise en valeur" of local resources (climate, scenery, coasts and countryside, mountains, etc.) by staging sports events.

For example, the professional surfing world championship "Quicksilver Pro France" is an international event held every year in the region of Aquitaine ${ }^{26}$ (South-West France). The event is highly complementary with the region's surfing identity and its staging is aimed at the "mise en valeur" of the most important local natural asset, that is the ocean coast.

What is interesting to note here is that Aquitaine developed a sport specialization (Hautbois, Desbordes 2008) in surfing, capitalizing on the vital importance of ocean for the local area. This sport specificity has boosted the region's socio-economic development (§. 2.1). In fact, Aquitaine's local context is characterised by an economic branch evolving around the surfing activity which comprises surfing schools, concept and design centres, textile R\&D centres, etc. Furthermore, some of the world's most important companies within this sector based in the region ${ }^{27}$ play an important role. They are not only main sponsor of the event, but also support research and development in the surfing sector with huge investment, thus contributing to the growth of the local productive system as one of the most innovative worldwide ${ }^{28}$.

Staging the Quicksilver world championship may also ensure an international promotion for Aquitaine. Giving the specificity of the event - which is addressed at surfers, athletes and passionates - it can contribute to fostering the region's image primarily towards worldwide surfer communities.

\subsection{Social urban regeneration ${ }^{29}$}

The transition from a manufacturing and goods-handling economy to the service economy of the 1980s has resulted in an urban economic decline especially in the traditional industrial areas of Europe. Some governance organizations modified the economic trajectory of their towns in a creative way, that is repositioning the city from an industrial to a cultural focus (Cooke 2005). Several European cities have (re)invented the significance of culture in its widest sense, including sports as an instrument of urban regeneration.

\footnotetext{
${ }^{25}$ For example, the city has established new wastewater treatment plants, solid-waste processing facilities, and green belts and built a fleet of clean buses for the games. Beijing replaced 47,000 old taxis and 7,000 diesel buses, and began requiring vehicles to meet EU emissions standards. In addition, natural gas (use of which is up tenfold), geothermal, and wind power are gradually replacing coal. Source: UNEP, October 2007.

${ }^{26}$ Usually sites of the event are Seignosse, Hossegon, Capbreton, and St. Jean de Luz. http://www.poleglisse.com.

${ }^{27}$ For example Quicksilver and Rip Curl. Source: http://www.poleglisse.com.

${ }^{28}$ Source: http://www.poleglisse.com.

${ }^{29}$ Regeneration is the term used to describe the process of economic redevelopment generally in an area that has suffered decline because of structural changes in the economy (Tribe, 2005). Here it is applied to urban contexts, but can be also referred to rural areas.
} 
Beside museums, festivals, exhibitions, etc. sport is an important tool to develop the cultural heritage of a city (Cooke 2005). Furthermore, sport can provide jobs, foster business activity and enhance community development. It can also stimulate a new sense of belonging to the city (Weed, Bull 2004).

Sport events have played an important part in economic development (§. 2.1) and social urban regeneration (§. 2.3, 2.4) strategies for cities such as Sheffield and Manchester in UK and Turin in Italy.

After having built its economic development on its steel and cutlery industries, during the 1970s and 1980s Sheffield's manufacturing base started to decline ${ }^{30}$. In response to its industrial demise, the city ${ }^{31}$ has pursued a sport economy policy, initiated by its staging of the 1991 World Student Games, aimed at developing a long-term regeneration process for the city, with a particular focus on the Don Valley, the area of the town that had suffered most from the city's deindustrialization (Weed, Bull 2004, Smith 2005). Staging the World Student Games has provided the city with the opportunity to reorient its image (Smith 2005) from "City of Steel" to "City of Sport" which helped attract 250 major sporting events to Sheffield between 1990 and 1996, boosting the local economy and attracting new business connected to sports facilities (restaurants, pubs, shops, guest houses, etc.)

The decline of Manchester's traditional industries (textile, engineering, and steel) intensified during the 1970s and early 1980s. The city's response has been to use sport as a crucial part of a central marketing initiative that involved football teams (Manchester United and Manchester City), cricket, swimming, and athletics. When Manchester bid for both the Olympics (2000) and the Commonwealth Games $^{32}$ (2002), regenerating the industrial urban landscape ${ }^{33}$ was a key motivating factor. Bidding and staging the Commonwealth Games have contributed to the development of worldclass sports facilities within this area, the generation of thousands of new jobs as a consequence, the construction of a metro line which improve connectivity to the city centre, universities and international airport, and the building of new houses ${ }^{34}$.

Sheffield and Manchester's municipal government partnered with the private sector agencies to attract major sports events. Once secured, such events have played a significant part in the economic and social revitalization of decaying industrial urban areas and in the built of "community identity" (§. 2.4).

At economic level, in both cities sporting facilities after the event have been used to boost new local activities. For example, in Manchester some sports building such as the football stadium Old Trafford became part of the leisure infrastructure of the city not only for tourists and visitors but also for local citizens. Besides being the venue for events (sporting and non-sporting), stadiums and arena

\footnotetext{
${ }^{30}$ The city lost 60,000 jobs between 1978 and 1988. Cfr. Dabinett G. (1990), Local Economic Development Strategies in Sheffield on the 1980's, CRESR Working Paper N. 10, Sheffield Polytechnic, Sheffield.

${ }^{31}$ In 1986 the Sheffield Economic Regeneration Committee in the City Council's Department of Employment and Economic Development was established which brought together representatives of the City Council, the business community, trade unions, higher education institutions, central government agencies and local organizations. See Dulac C., Henry I. (2001), "Sport and social regulation in the city: the cases of Grenoble and Sheffield", Society and Leisure, Vol. 24, N. 1, Spring, pp. 47-78.

${ }^{32}$ The Commonwealth Games are staged every four years in British Commonwealth destinations and involve athletes coming from 53 states, most of which are former British colonies.

${ }^{33}$ At the end of the 1990s the East Manchester district (where the old industrial factories were placed) was characterised by many of the socio-economic conditions and problems of many other inner city areas in Britain. In addition to the economic decline and population loss, the area had key problems such as a low skills base within the local working age population, high crime rates, high levels of unemployment, poor quality infrastructure.

${ }^{34}$ Source: http://www.gameslegacy.co.uk.
} 
are also a focal point for much leisure-related investment. The city's multipurpose facilities (restaurants, museums, merchandising shops, etc.) are an "economic catalyst" (Lago, Baroncelli, Szymansky 2004) for commercial and entrepreneurial local business activities - such as restaurants, clubs, bars, etc. - placed close to the sport venue.

At a social level, sport facilities which have hosted specific tournaments like tennis, ice hockey, swimming, and the like have been reconverted into public venues in order to attract promising athletes, nurturing local talents and building a more active local community with access to sporting opportunities.

Another interesting case is when a major sports event emerges as a main driver of "reimaging a city" (Smith 2005). Turin, which staged the 2006 Winter Olympics, is one such case.

Turin is known worldwide as Italy's car manufacturing capital, stronlgy connected with FIAT, which has given the city its well-known image of a "one company town". Recently Turin has faced a period of intense change of identity due to a process of de-industrialization. This is shown by its urban transformation that has occurred in the attempt to diversify its local economy.

Besides the economic impact in terms of added income, new job creation and increased tourist expenditures (see §. 2.1), the Olympics have marked the transition of Turin from industrial city to cultural urban centre. The choice of tourism, sports, leisure services and culture as new "core business" of the city, has become strategic after the bid for the Games while early it was solely "interstitial".

\subsection{Changing the unequal participation in the global economy and building positive tourism destination image}

In some cases the potential of a sport event can be harnessed to raise international profile and change the perceptions of a country as a tourist destination. For example, the bid for the 2010 football World Cup in South Africa represents an important occasion for a national "booster" that may reposition this developing country's interests in the global economy. In the case of South Africa, staging an international event has the potential to advance economic development in terms of creating new jobs and increasing tourist expenditures and foreign business investments. According to a consulting company (Grant Thornton, 2003), the hosting of the World Cup will contribute more than R21 billion to the country's Gross Domestic Product (GDP) and create in excess of 150,000 new jobs. Showcasing the region and its natural beauty should enhance South Africa's reputation as an attractive tourist destination. Brand new infrastructures needs could be highlighted in order to further promote investment in the country. More convenient and modern venues are likely to attract higher numbers of spectators and perhaps host upcoming similar major events (Bohlmann, Van Heerden 2008). The indirect benefits of an improved image abroad could have an even greater impact on the economy by contributing to changes in the perceptions held by some foreign investors on Africa and South Africa in particular.

The impact of the World Cup will be very relevant even in terms of the both sporting and nonsporting related infrastructures development. By 2010, South Africa will have spent in the region of R5 billion on building and renovating 10 World Cup stadiums, R5.2 billion on upgrading the airports, and R3.5 billion on improvements to the road and rail network (Grant Thornton 2003).

From a social perspective, the international football event can have a great potential for the community development and nation-building in South Africa (Keim 2006). 
South Africa is an attractive tourist destination due to its natural and cultural resources, based on its many World Heritage sites, its rich fauna, and the many international fairs and exhibitions held in the country. However there are also some areas of weakness that have brought down the country's overall perception (World Economic Forum 2008) such as the large poverty levels as a high percentage of population (43\% live on under R3000 per annum) ${ }^{35}$. Safety and security are a serious concern, with the costs of crime and violence in particular. The country also has weaknesses in the area of health and hygiene. South Africa's life expectancy is low, at 48 years, related in large part to the very high rates of communicable diseases such as HIV/AIDS.

Even if sport event organization cannot represent a long-lasting solution to South Africa's problems, it can prove an useful instrument in facilitating the economic and social development (Keim 2006). Sport has global appeal because it teaches life skills such as communication, cooperation and leadership, promotes respect and fair play, encourages participation of marginalized groups, attracts interest from the media and can bridge social, cultural and religious divides. If South Africa's government acknowledges this power, the football event might offer an unparalleled opportunity to raise awareness about the many significant contributions made by sports towards achieving relevant goals $^{36}$ - such as reducing poverty, increasing primary education, ensuring environmental sustainability, etc. - which in turn will make the country more appealing for foreign investors and thus increasing sustainable economic development.

\section{Concluding remarks}

To build a classificatory map of the tentative empirical evidence correlated to host economy qualitative development, an attempt is made to build an exhibit which sums up the different typologies identified in section 3 (see Exhibit 2). For each typology the exhibit highlights the extent to which indicators and sub-elements discussed above (\$.2) impact the qualitative development of the host economy $^{37}$. It has to be said that the exhibit contains a primary attempt of impact evaluation which has been drawn from the case studies evidence. The proposed evaluation is therefore not expected to be exhaustive and does not mean a definitive assessment.

In this regard, time is a variable which can have a relevant influence on typologies' identification. It is possible that in the long-term some of the indicators and sub-elements not yet considered within a specific case study would have a much greater impact, thus modifiying the whole development process of the host economy. Time is also important in this analysis since an event like South Africa 2010 (§. 3.5) is going to be staged in the near future. Therefore effects evaluation can only be forecast. In the other cases the evaluation is ex-post and has been more meaningful, especially when major events occurred many years ago.

One example is Barcelona, the "oldest" event cited in this research (§. 3.1). For this city it is possible to make a much more articulated analysis of the Olympics' impact since the effects of this event have emerged in the long term to such an exent that they can be referred to as the "Barcelona

\footnotetext{
${ }^{35}$ See United Nations, South Africa's Millennium Development Goals (MDG) Mid-Term Country Report, September, 2007.

${ }^{36}$ See footnote 38 .

${ }^{37}$ Within each typology is made an evaluation concerning the specific case study analyzed. Each case study is marked with a capital letter (see the $*$ in the box below the exhibit). The evaluation ranges from a minimum impact value (1 letter) to a maximum (3 letters). Some spaces in the exhibit have been deliberately left blank. It means that the impact of major sports events on that specific sub-element (i.e. social inclusion, FDI, etc.) is not relevant, even if to some extent it exists.
} 
model" in terms of urban, infrastructural and image transformation. Barcelona has been the first example of a city using the Olympics with the purpose of promoting its image as a city of culture and in this process it suffered from global competition to a lesser extent than today. Nowadays the strategy to stage a major sports event in order to increase the attractiveness of a place is well known. Cities that are candidates to host the Olympics or the football World Cup have to compete with several cities to be on the "global map". Within a global economy, culture or attractive scenery are not enough. Cities need to be in excellent positions in terms of high-level tourism facilities, technology infrastructure and environmental sustainability if they want to gain a competitive advantage over their competitors.

Valencia (§. 3.1) appears very similar to Barcelona even if the America's Cup only concluded one year ago so that it is not possible to make an exhaustive evaluation concerning some indicators such as future tourism increases. Anyway it can be argued that Valencia with its purpose of becoming an attractive urban pole for the Spanish south coast and even for Europe, re-proposed the same strategic tools as Barcelona in 1992 (enhanced infrastructure, rejuvenation of old part of the town, harbour restoration, etc.) but within a role of follower.

In light of the research a consideration emerges that besides time, other variables have relevant effects on the different qualitative development of host economies.

Major sports events' implications in the long term seem to be guided by a path-dependance development process. This means that the ability to strategically plan and manage the event are influenced by the set of resources (natural, historical, entrepreneurial, etc.) and capabilities deeply rooted in the local context. Concerning Barcelona it is significant that since the end of the $19^{\text {th }}$ century the city has started a process for promoting itself with an image of "Capital and cosmopolitan city" hosting international cultural exhibitions (i.e. the Universal Exhibition in 1888 and in 1929) and "monumentalising" some urban spaces and architecture (Monclùs 2000). Once again, after a hundred years, Barcelona tried to improve its prestige by staging an international sports major event such as the Olympics. Culture, with sport activities as an important part of the cultural heritage of a city (Cooke, 2005), is the file rouge for Barcelona's global image promotion.

In the case of the Aquitaine region, the socio-economic development evolved around the world surf championship through the "mise en valeur" of a local natural asset (the ocean) and the strategic supportive role of local surfing companies (\$. 3.3).

From other examples it emerges how history, culture and tradition of a host economy can impact on some managerial aspects of major sports events. For example, from the table 1 Sheffield and Manchester resemble Turin in terms of economic, social and tourism impact (\$. 3.4). Actually, the UK and Italian cases are pretty much different, in particular regarding the provision of post-event sporting facilities to the local community. In post-industrial areas of UK, stadiums and arena become multipurpose sites and are places where people spend a great part of their leisure time with their families, shopping, eating and drinking - in essence doing activities that are not directly linked to sport. Stadiums become a sort of shopping mall and that is a successful model here where there are any other local assets (natural, historical, artistic, etc.) to be exploited. In Turin, where the post-use of sport facilities for the local community has been relevant too, these venues have been perfectly integrated into the cultural, artistic and social attitude of the city. Some of the sports buildings located in the ex-FIAT's industrial area (i.e. the Lingotto) have been embodied within the new image of the city as new locations for art exhibitions, congress centres and universities. The industrial history of Turin has been therefore embedded within the cultural heritage of the city. 
Table1. A tentative typology of tourism destinations development

\begin{tabular}{|c|c|c|c|c|c|}
\hline & $\begin{array}{c}\text { Putting } \\
\text { "periphery" } \\
\text { destinations on } \\
\text { a global map } \\
\end{array}$ & $\begin{array}{c}\text { Driving } \\
\text { economies of } \\
\text { emerging } \\
\text { markets }\end{array}$ & $\begin{array}{l}\text { "Mise en } \\
\text { valuer" of } \\
\text { local assets }\end{array}$ & $\begin{array}{l}\text { Social urban } \\
\text { regeneration }\end{array}$ & $\begin{array}{c}\text { Changing } \\
\text { unequal } \\
\text { participation on } \\
\text { global economy }\end{array}$ \\
\hline \multirow{3}{*}{$\begin{array}{l}\text { Economic impact } \\
\text { - added value } \\
\text { - new jobs } \\
\text { - FDI }\end{array}$} & $\mathrm{BB} ; \mathrm{VV}$ & $\mathrm{CH}$ & AA & $\mathrm{S} ; \mathrm{M} ; \mathrm{T}$ & SASA \\
\hline & $\mathrm{B} ; \mathrm{VVV}$ & $\mathrm{CH}$ & AA & SS; MM; TT & SASA \\
\hline & $\mathrm{BB} ; \mathrm{V}$ & $\begin{array}{l}\mathrm{CHCHCH} ; \\
\text { MEME }\end{array}$ & & & SA \\
\hline $\begin{array}{l}\text { - tourists' spending } \\
\text { during the event }\end{array}$ & $\mathrm{B} ; \mathrm{VV}$ & $\mathrm{CH} ; \mathrm{ME}$ & A & $\mathrm{T} ; \mathrm{S} ; \mathrm{M}$ & SA \\
\hline $\begin{array}{l}\text { - boosting local } \\
\text { economy }\end{array}$ & $\mathrm{B} ; \mathrm{VV}$ & $\mathrm{CH} ; \mathrm{ME}$ & AAA & MM; SS & SA \\
\hline $\begin{array}{l}\text { Tourism } \\
\text { - reposition of a place } \\
\text { as a tourist centre } \\
\text { - enhance local } \\
\text { economy in decline } \\
\text { through tourism }\end{array}$ & BBB; VVV & $\begin{array}{l}\text { CHCH; } \\
\text { MEMEME }\end{array}$ & A & SS; MM; TT & SASA \\
\hline \multirow{3}{*}{$\begin{array}{l}\text { Urban renewal } \\
\text { - new or renewed } \\
\text { physical } \\
\text { infrastructure } \\
\text { (sporting/non } \\
\text { sporting) } \\
\text { - housing } \\
\text { - leisure facilities }\end{array}$} & BBB; VVV & $\begin{array}{l}\text { CHCHCH; } \\
\text { MEMEME }\end{array}$ & A & SS; MM; TT & SASA \\
\hline & BB; & $\mathrm{CHCH}$ & & $\mathrm{S} ; \mathrm{M}$ & SA \\
\hline & $\mathrm{BB} ; \mathrm{VV}$ & $\begin{array}{c}\text { CH; } \\
\text { MEMEME }\end{array}$ & A & SS; MM; TT & SA \\
\hline - re-imaging a place & $\mathrm{BBB} ; \mathrm{VV}$ & $\mathrm{CHCH}$ & & $\begin{array}{l}\text { SSS; MMM; } \\
\text { TTT; }\end{array}$ & SA \\
\hline \multicolumn{6}{|l|}{ Socio-cultural impact } \\
\hline $\begin{array}{ll}\text { - } & \text { community } \\
\text { development }\end{array}$ & $\mathrm{B} ; \mathrm{V}$ & $\mathrm{CHCH}$ & A & $\mathrm{S} ; \mathrm{M}$ & SASA \\
\hline - social inclusion & & & & $\mathrm{S} ; \mathrm{M}$ & SA \\
\hline - nation building & & $\begin{array}{l}\text { CHCH; } \\
\text { MEME }\end{array}$ & & & SASASA \\
\hline $\begin{array}{l}\text { - employment } \\
\text { opportunities }\end{array}$ & & & & SS; MM & SA \\
\hline $\begin{array}{l}\text { Environmental impac } \\
\text { - natural environment } \\
\text { (pollution, recycling } \\
\text { system, energy saving, } \\
\text { etc.) }\end{array}$ & $\mathrm{B} ; \mathrm{VV}$ & $\begin{array}{l}\text { CHCHCH; } \\
\text { MEME }\end{array}$ & AA & $\mathrm{S} ; \mathrm{M} ; \mathrm{TT}$ & SA \\
\hline $\begin{array}{l}\text { - post-use facilities: } \\
\text { - future staging of } \\
\text { sports events }\end{array}$ & $\mathrm{BB} ; \mathrm{VV}$ & MEME & & SS; MM; TT & \\
\hline $\begin{array}{l}\text { - facilities for local } \\
\text { community }\end{array}$ & $\mathrm{BBB} ; \mathrm{VV}$ & $\mathrm{CH}$ & AA & $\begin{array}{c}\text { SSS; MMM; } \\
\text { TT }\end{array}$ & SA \\
\hline
\end{tabular}

* A=Aquitaine; $\mathrm{B}=$ Barcelona; $\mathrm{CH}=$ China; $\mathrm{M}=$ Manchester; $\mathrm{ME}=$ Middle East; $\mathrm{S}=$ Sheffield; $\mathrm{SA}=$ South Africa; $\mathrm{T}=$ Turin; $\mathrm{V}=$ Valencia

The socio-economic development can be different also in terms of the event scale. Although this research only considered major sports events (§. 1), there are some particularities of the Olympics as regards to the others created not only by the complexity of organizing the Olympic games, but also by the global visibility which a host country can gain through staging them. 
Hosting the Olympics requires a tremendous amount of resources (human, technological, financial, economic, etc.) and capabilities (safety and security management, logistic, organizational, etc.) that go into their implementation (Hiller 1998). But what primarily differentiates the Olympics from any other major event is the strength of the bid which affected the political, economic, demographic, social and environmental situation of a candidate city (Theodoraki 2007). The host destination has to start planning for the games as soon as it is elected by the IOC (International Olympic Committee) and the Olympic organizing commitment should "pervade" every aspect of people's daily lives until the opening ceremony ${ }^{38}$ and later on in the post-event period.

Furthermore, the Olympics can have huge implications not only for the image of a host city, but for a country as a whole. For example during the 2006 Winter Olympics not only Turin but Italy as a whole had to demonstrate that it was able to manage the games primarily in terms of safety and security against the terrorism threat. The successful Games, not only from a sporting perspective but also security management, played an important role in revitalizing the image of Italy on the international market place, providing an added value which goes beyond the event and which may influence the attractiveness both of Italian products and the country as a tourist destination (Zagnoli, Radicchi 2008a).

Other major sports events such the America's Cup, even to a lesser extent than the Olympics, however require a massive financial, economic and infrastructural investment. Certainly having constant wind conditions which could minimize the risk of cancelled races helped Valencia to win the bidding for the 2007 Louis Vuitton Cup. But most importantly, the city made a huge capital investment in nautical infrastrucure (\$. 3.1) and won the competition with the other candidates (i.e. Naples) by having facilities which allowed the most efficient sailing boat movement and a faster access to the sea.

As a whole the case studies proposed in this research seem to have positive outcomes from staging major sports events. However there can be negative aspects of hosting a sports event too. Issues relating to the use of the natural environment, the negative effects on local communities and visitor conflicts such as sports spectators disorder and the like all need to be stategically addressed and planned by sporting and non-sporting local governments and authorities if major sports events are to create a long-term value for the host economy.

\section{REFERENCES}

Allen, J., O’Toole, W., McDonnel, I. and Harris, R. (2000). Festival and Special Event Management. Sidney, Australia: John Wiley \& Sons.

Bohlmann, H.R., Van Heerden, J.H, (2005). The Impact of Hosting a Major Sport Event on the South African Economy, Working Paper no 2005-09, University of Pretoria. http://web.up.ac.za/UserFiles/WP-9.pdf. [Consulted 30/05/2008].

Bohlmann, H.R., Van Heerden, J.H, (2008). Predicting the Economic Impact of the 2010 FIFA World Cup on South Africa. International Journal of Sport Management and Marketing, Vol. 3, no 4, pp. 383-396.

Bonadies, B. (2008). Tecnologie Costruttive e Materiali. Convegno "Energia, Sport e Ambiente". Giugno: Coni Firenze.

Bontje, M., Pareja, M. (2007). Attracting creative knowledge: strategies towards competitiveness in Amsterdam and Barcelona, Paper presented at the International Conference on "Sustainable Urban Areas", 25-28 June, Rotterdam, pp. 1-20 http://www.enhr2007rotterdam.nl/documents/W11_paper_Bontje_Pareja.pdf. [Consulted 02/06/08]

Bowdin J., Allen J., O’Toole W., Harris R. and McDonnel I. (2006). Events Management, Elsevier.

\footnotetext{
${ }^{38}$ For example China since 2000 has been running a program which encouraged people to use public transport rather than private cars.
} 
Carbone E. (2007). The role played by sport in sustainable development. SpazioSport, no 3, Luglio/Settembre, pp. 8-9.

Chalip, L. (2006). Toward social leverage of sport events. Journal of Sport and Tourism, Vol. 11, pp.109-127.

Chalkey, B., Essex, S. (1999). Urban development through hosting international events: A history of the Olympic Games. Planning Perspectives, Vol. 14, pp. 369-394.

Coalter, F., Allison, M. and Taylor, J. (2000). The role of sport in regenerating deprived areas. Scottish Executive Central Research Unit.

Dabinett, G. (1990). Local Economic Development Strategies in Sheffield on the 1980's, CRESR Working Paper no 10. Sheffield: Sheffield Polytechnic.

Dulac C., Henry I. (2001). Sport and social regulation in the city: the cases of Grenoble and Sheffield. Society and Leisure, Vol. 24, no 1, Spring.

Ferran, B. (2004). The economic impact of the Barcelona Olympic Games, 1986-2004, Faculty of Economics and Business Study, Universitat Autonoma de Barcelona. http://olympicstudies.uab.es/pdf/wp084_eng.pdf. [Consulted 10/06/2008].

Euromonitor International. Travel and Tourism in the United Arabs Emirates. Report, 2008.

Getz, D. (1997). Event Management and Event Tourism. New York: Cognizant Communications Corporation.

Grant, T. (2003). SA 2010 Soccer World Cup Bid Executive Summary, http://www.polity.org.za. [Consulted 02/06/08].

Hall, C.M. (1992). Hallmark Tourist Events: Impacts, Management and Planning. London: Belhaven Press.

Hautbois, C., Desbordes M. (2008). Sport et Marketing Public. Paris : Economica.

Jones, C. (2005). Major events, networks, and regional development. Regional Studies, Vol. 39, pp. 185-195.

Higham, J. (2005). (Eds.) Sport tourism destinations. London: Elsevier.

Hiller, H.H. (1998). Assessing the impact of mega-events: a linkage model. Current Issues in Tourism, Vol. 1, no 1, pp. 47-57.

Instituto Valenciano de Investigaciones Economicas (IVIE) (2007). Final Report on the Economic Impact of the $32^{\text {nd }}$ America's Cup Valencia 2007.

Law, C.M. (2000). Regenerating the city centre through leisure and tourism. Built Environment, Vol. 26, pp. 117-129.

Lee, C., Taylor, T. (2004). Critical reflections on the economic impact assessment of a mega-event: the case of 2002 FIFA World Cup. Tourism Management, Vol. 26, Issue 4, August, pp. 595-603.

Kaspar, R. (2001). Sport, environment and culture. Journal of Sport and Science, Vol. 22, no 4, pp.17-19.

Keim, M. (2006). Sport as Opportunity for Community Development and Peace Building in South Africa. In Auweele Y., Malcolm C. and Mulders B. (Eds.) Sport and development. Leuven, Belgium: Lannoo Campus, pp. 97-106.

Koivusalo, S. (2005). Promoting Eco-efficiency in sports events. Sport Summit for the Environment. Helsinki: University of Technology, Nogoya.

Kotler, P., Haider, D., Rein, I. (2002). Marketing Places: Attracting Investment, Industry and Tourism to Cities, States and Nations. Free Press.

Kurtzman, J. (2005). Economic Impact: Sport Tourism and the City. Journal of Sport Tourism, Vol. 10, no 1, pp. 47-71.

Masterman, G. (2004). Strategic Sports Event Management. An international approach. Oxford-MA: Elsevier.

Metro Atlanta Chamber of Commerce (2006). 10 years later: Atlanta's Olympic legacy is still transforming city. http://www.metroatlantachamber.com/images/olympiclegacy.pdf. [Consulted 10/06/2008].

Miami, H. (2007). Super Bowl: How much is it really worth? May $26^{\text {th }}$.

Ministry of Environment (2005). Physical Planning and Public Works. Regeneration of Faleron Bay, Olympic Projects 2004. 
Monclùs, F.J. (2000). Barcelona's Planning Strategies: From 'Paris of the South' to the 'Capital of West Mediterranean. GeoJournal, Vol. 51, pp. 57-63.

Moragas, M., Rivenburgh, N., and Garcia, N. (1995). Television and the construction of identity: Barcelona, $\begin{array}{lllll}\text { Olympic host, Centre Olímpics UAB, Barcelona } & \end{array}$ http://www.olympicstudies.uab.es/pdf/wp033_eng.pdf. [Consulted: 11/06/08].

OMERO - Olympics and Mega Events Research Observatory (2006). Quinta Indagine sulle Olimpiadi Invernali 2006. I Torinesi e l'esperienza dei Giochi: un bilancio post-evento. Marzo: Università di Torino.

Payne, M. (2007). A Gold-medal Partnership. Strategy+Business, Issue 46, Spring, pp. 1-12.

Preuss, H. (2000). Economics of the Olympic Games - Hosting the Games 1972-2000. Walla Walla Press in conjunction with the Centre for Olympic Studies.

Preuss, H. (2007). Signaling Growth: China's Major benefit from Staging the Olympics in Beijing 2008. Harvard Asia Pacific Review, Winter, pp. 41-45.

Radicchi, E. Business Models in a New Media Context: Comparing Four U.S.-based Sport Leagues, Ph.D. Thesis, Università di Firenze, 2007.

Resciniti, R. (2004). Il marketing orientato all'esperienza. L'intrattenimento nella relazione con il consumatore. Napoli: Edizioni Scientifiche Italiane.

Ritchie, J.R.B. (1984). Assessing the impact of hallmark events: conceptual and research issues. Journal of Travel Research, Vol. 23, no 1, pp. 2-11.

Roche, M. (2000). Mega-Events and Modernity: Olympics and Expos in the Growth of Global Culture. London: Routledge.

Smith, A. (2005). Reimaging the city. The value of sport initiatives. Annals of Tourism Research, Vol. 32, no 1, pp. 217-236.

Spanberg, E. (2003). Collection of NASCAR shops turns May races into tourist season for Charlotte. Sports Business Journal, 26 May.

Theodoraki, E. (2007). Olympic Event Organization. London: Elsevier.

Tribe, J. (2005). The economics of recreation, leisure and tourism. London: Elsevier.

United Nations, South Africa's Millennium Development Goals (MDG) Mid-Term Country Report. September, 2007.

Van Heerden, J.H., Gerlagh, J., Blignaut, J., Horridge, M., Hess, S., Mabugu, R. and Mabugu, M. (2006). Searching for triple dividends in South Africa: Fighting CO2 pollution and poverty while promoting growth. Energy Journal, Vol. 27, no 2, pp. 113-142.

Varaldo, R. (2002). L'industria del tempo libero: profili e prospettive. In Resciniti R. (Eds.) Economia e Marketing del tempo libero. Milano: Franco Angeli, pp. 41-55.

Weed, M., Bull, C. (2004). Sport Tourism. Participants, policy and providers. Oxford-MA: Elsevier.

Wei, Y.H.D., Yu, D.L. (2006). State policy and the globalization of Beijing: Emerging themes. Habitat International, Vol. 30, pp. 377-395.

Whitson, D. (2004). Bringing the world to Canada: The periphery of the centre. Third World Quarterly, Vol. 25, no 7 , pp. 1215-1232.

Whitson, D., Macintosh, D. (1996). The global circus: international sport, tourism and the marketing of cities. Journal of Sport and Social Issues, Vol. 23, pp. 278-295.

World Economic Forum. Travel and Tourism Competitiveness Report, 2008.

Yin, R.K. (2002). Case Study Research, Design and Methods. 3rd ed. Newbury Park: Sage Publications.

Zagnoli, P., Radicchi, E. (2008a). Sport Marketing. Il nuovo ruolo della comunicazione, 2nd ed., Milano: Franco Angeli.

Zagnoli, P., Radicchi, E. (2008b). Lo sport come veicolo di marketing esperienziale: attori, relazioni e tipologie di esperienza reale e virtual. Mercati e Competitività, Milano: Franco Angeli, Forthcoming. 